\title{
The Perceptions of Students Studying at a Vocational School on the Role of English in Their Lives and Their Reasons to Learn English
}

\author{
Semahat Aysu (Lecturer) \\ Tekirdağ Namık Kemal University-Turkey \\ saysu@nku.edu.tr
}

\begin{abstract}
:
English as a foreign language has been learnt and taught in Turkey for many years. Although the role of English in students' lives is the subject of a number of studies, there is little research on the perceptions of students studying at vocational schools. Therefore, the purpose of this study is to explore the perceptions of students studying at a vocational school about how English affects their professional and their social life. Considering the purpose of the study qualitative research method was applied. Ten volunteer students studying Tourism and Hotel Management and Accounting and Tax Application participated in the semistructured interview. Data gathered from interviews were analyzed using thematic analysis. The results revealed two themes which were the perceptions of students towards learning English and their reasons to learn English. The first theme consists of positive attitudes and negative attitudes and the other theme has three codes which are as follows: profession, communication and entertainment.
\end{abstract}

Keywords: English teaching, English learning, Vocational school, Foreign language

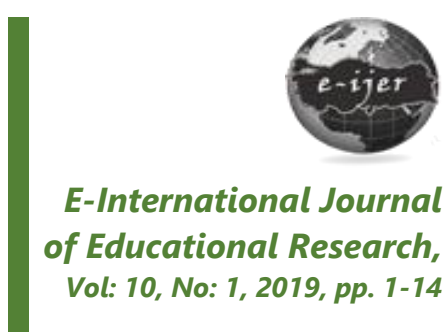

DOI: 10.19160/ijer.392673

\section{ÖnerilenAtıf}

Aysu, S. (2019). The Perceptions of Students Studying at a Vocational School on the Role of English in Their Lives and Their Reasons to Learn English, E-International Journal of Educational Research, Vol: 10, No: 1, 2019, pp. 31-48, DOI:10.19160/ijer.392673 


\section{INTRODUCTION}

The importance of knowledge of foreign languages in today's world is not difficult to understand since the world is smaller (Johnson, 2013; Sarıçoban, 2012) with the lack of boundaries and with the rapid spread of knowledge "by radio, television, cinema and other mass media" and today "by the internet and social media" (British Council, 2013, p. 6). Therefore, people learn foreign languages for many reasons and Johnson $(2013$, p. 5) summarizes them as follows: "study purposes, integration with different culture, intra-national communication and international communication". Additionally, the reasons of learning foreign languages are presented by Weatherford (1986, p. 3) as follows: "increased activity in international business, the inflow of large amounts of foreign capital to the United States, increased internationalization, and expanded awareness of the need to conduct not only business but also diplomatic relations in the language of the host country". People learn and speak foreign languages in order to have some advantages for job market, career, travel opportunities, and mutual communications (Weatherford, 1986).

Doms (2003, p. 4) particularly emphasizes the importance of English as a foreign language. According to him the reason is that "leading-edge information and communication technology is largely based in the U.S." (p.4) and other nations learn English as a foreign language to follow them. Moreover, Sarıçoban (2012, p. 2643) also notes that the knowledge of English is "an indispensable part of the modern world" and learning English is necessary in order to keep up with "the communicational requirement of the modern world".

In Turkey the most commonly learnt and taught foreign language in use is English. Erdel and Akalın $(2015$, p. 2) identify the place of English in Turkey with these words: English is a major language for "science, technology, international relations and in many other social, cultural and economical aspects of modern and intellectual life" in Turkey. The findings of research conducted by Özen, Alpaslan, Çağlı, Özdoğan, Sancak, Dizman, Sökman (2013, p. 10) show the importance of knowing English for an individual and a country since it is the "main language of communication in the world" and they summarize the importance of English below.

In particular, the English language is increasingly important as a means of communication and interaction among different cultures; for increasing innovation and the relative sophistication of exports; for increasing trade relations through connectivity; for key sectors such as tourism and for individual job prospects.

The study carried out by Dogancay-Aktuna (1998) examines two Turkish newspapers and finds out that $22 \%$ of job advertisements were printed in English. This shows that even the year of 1998 witnessed the importance of English in job market and today the knowledge of English is much more necessary for job market. Moreover, Gömleksiz (2010, p. 913) mentions in his study that "the English language is a key to success in life". This conforms to the findings of the study conducted by Erdel and Akalın (2015) since they reveal that in Turkey students learn English for the purpose of success in professional and social life.

Regarding the use of English and its importance as a foreign language in Turkey, various studies have been conducted in different educational levels in order to see the effects of knowledge of English on learners' lives. Karahan (2007) investigates primary school students' attitudes towards English and the use of English in Turkey. She finds out that students do not have high positive attitudes towards English but they accept that English is the most frequently used foreign language in Turkey. Moreover, the study conducted in high school by Uztosun (2011) demonstrates that English is a tool for students to be successful in university examination. Besides the research in primary school and high school, the study which is carried out in preparatory school of a university by Öztürk (2015) reveal that students are motivated to learn English and 
they believe that learning English will contribute to their career, social status and academic success.

Consequently, as the studies show, English as a foreign language has a prominent role in Turkey and learners' perceptions on the role of English in their lives have been investigated in different educational levels so far. It is revealed that the views of students on the role of English in their lives will be useful for language teaching planning and language teaching process (BaniKhalad, 2014). When teachers know and understand the views of students about learning English, they design effective lessons considering the students' needs and thus, students will learn English and benefit from the knowledge of English to be successful in their professional and social life (Öztürk, 2015). Apparently, there is a lack of study which particularly examines vocational school students' views on the role of English in their lives in depth. Therefore, this current study will be conducted in a vocational school in order to reveal the perceptions of students on the role of English in their lives in terms of their professional and their social life.

\section{The Role of a Foreign Language in the Individuals' Life}

Learning a foreign language means learning another language besides one's own native language. That is, learning a foreign language allows one to express self and understand others by the means of a different language rather than one's native language (Zaim, 2011). Genesee and Cloud (1998, p. 62) note the benefits of knowing a foreign language and add that second or even third languages should be learnt "if we are to live comfortably in multilingual, multicultural neighborhoods, compete successfully in the global marketplace, and take full advantages of communication technologies". According to them, the individuals benefit from the knowledge of foreign language and these benefits are listed as follows: working benefits, educational benefits, cognitive benefits and socio-cultural benefits.

First of all, knowing a foreign language provides "more job opportunities and higher salaries" not only for translators or language teacher but also the professionals in other sectors (Jeffery, 2008, p. 7). Genesee and Cloud (1998) state that world is a global village with the advancement of communication technologies and there are no barriers to communicate. Therefore, people who know at least one foreign language can have an advantage from this since they will be preferred for the jobs (Genesee and Cloud, 1998). Tomak (2011) also gives example in his study that the companies hire people who know at least one foreign language.

Secondly, as educational benefits it could be stated that students who know a foreign language make use of advantages such as studying abroad or having prestigious scholarships like Fulbright Program (Jeffery, 2008). Furthermore, the report of Euromonitor International (2010) presents that a degree that an individual gets from a university in a developed-English speaking country will provide an advantage and a social status when he/she comes back home country.

Thirdly, Bialystok and Hakuta (1994) explain the cognitive benefits of foreign language and they draw our attention to a research in Canada which investigates English-language test performance of bilingual students (who know English and French) and monolingual students (who know English). It shows that bilingual students outperform monolingual students on cognitive tasks. The underlying reason is that learning a foreign language increases mental capacity and improves problem-solving skills of individuals (Jeffery, 2008).

Finally, the last benefit of foreign language is socio-cultural benefit. Singhal (1997) states a foreign language helps the individuals to understand and appreciate the differences among different cultures with the intercultural understanding and tolerance since this new language gives the opportunity to communicate with others. Similarly, Weatherford (1986) and Stewart (2005) point out that studying a foreign language helps the individuals have sympathy for other people and cultures.

Besides the benefits of knowing a foreign language, learning a foreign language requires the individuals' dedication, time and effort. Zaim (2011: 12) admits that learning a foreign 
language is not so easy since it needs "an investment of time and money, depending on the route chosen".

As a conclusion, there are both benefits and difficulties to learn a foreign language. Since the process of learning language is not easy and it requires an individual his/her time and effort, the individual may give up learning a foreign language easily if he/she is not patient and tolerant enough. But if he/she learns a foreign language, he/she can benefit from it economically, educationally, cognitively and socio-culturally. In this respect, a Turkish proverb explains the importance of the knowledge of language well "One who speaks only one language is one person, but one who speaks two languages is two people".

\section{Previous Studies on the Role of English as a Foreign Language in the Individuals' Life}

As it is mentioned above knowledge of foreign language may affect people' lives in both positive ways and negative ways but the benefits of foreign language knowledge outweigh the drawbacks of foreign language knowledge. Therefore, the role of English as a foreign language in individuals' lives has attracted many researchers' interests so far and they investigate the role of English used as a foreign language in the people's lives in different contexts and different educational levels (Bani-Khalad, 2014; Erdel and Akalın, 2015; Gömleksiz, 2010; Hann, Timmis, Alkhaldi, Davies, Troncoso and Yi, 2014; Karahan, 2007; Önder-Özdemir, 2014; Öztürk, 2015; Tardy, 2004; Tomak, 2011). Among these researchers Hann et al. (2014) conduct a comprehensive study in five sites: Abu Dhabi, Bogota, Shandong, Leeds and Salford and they examine the effect of English learnt as a foreign language or as a second language on students' lives. They gather data through three research tools: brain storming and ranking activity, timeline template and interview. They reach seven themes which show the reasons of students to learn English. These themes are communication, education and work, travel, making friends, leisure and relationships, technology, knowledge and understanding of the world and negative impact. This study demonstrates that learning English widens students' relationships, helps to reach different cultures beyond their native culture, increase their knowledge and understanding the world and communicate with different people around the world.

Karahan (2007), Gömleksiz (2010) and Bani-Khalad (2014) are interested in the attitudes of students who learn English as a foreign language towards learning English. While Karahan makes her investigation in primary school, Gömleksiz and Bani-Khalad examine undergraduate students' attitudes. Karahan and Gömleksiz find out that female students have more positive attitudes towards learning English than male students. Furthermore, female students believe that English as a foreign language is necessary and useful in Turkey but it is not used for interaction in daily life. Therefore, students do not make effort to learn English until they become aware of its necessity for their job. On the other hand, the findings of Bani-Khalad suggest that there is no significant difference in terms of students' gender and all the students have positive attitudes towards learning English and they agree that English as a foreign language is an important language in individual's personal and professional life.

The research of Erdel and Akalın (2015) which is conducted in three faculties and two vocational schools of a state university and another study which is carried out by Öztürk (2015) in the preparatory school of a university investigate the students' opinions about the role of English in their lives. Both studies in Turkish context reveal that students accept the importance of English in the world and they learn English since it will help for their career, individual and academic success in the future. Additionally, the findings of conducted study by Tomak (2011) in the preparatory school of a state university also reveals that people in Turkey learn English in order to use it for communication purposes with people from various countries. Furthermore, Uztosun (2011) also investigates the role of English in the lives of students studying at language division 
at high school. He finds out that English language is a tool to be successful at the university entrance examination for these students.

Önder-Özdemir (2014) conducts a study with Turkish post-graduate students studying in the UK and the USA and she examines these students perceptions related to the benefits and drawbacks of English in the scientific communication. She finds out that all the participants agree that English is the major language for communication in the science, for interaction with people, for opportunity to attend international conferences or to apply for the international research fund. Participants describe English with these adjectives "universal, scientific, dominant, common, essential, main and primary" (p. 75). Apart from the benefits, they state the drawbacks of English in scientific communication. For example, they cannot use Turkish in international conferences, they have difficulties to express themselves in English and they feel discrimination from the native speakers of English due to the mispronunciation or incorrect grammar.

Considering the studies which investigate the role of English in peoples' lives in the relevant literature, students' attitudes towards learning English is "one of the leading predictors of success in learning English" (Gömleksiz, 2010, p. 913) and identifying students' negative attitudes will provide opportunity for the teachers to change them into positive attitudes (Oroujlou and Vahedi, 2011). Moreover, knowing the reasons why students want to learn English will increase the effectiveness of language learning and teaching process(Hann et al., 2014) since the teacher will motivate them accordingly and students will actively participate in the lesson in order to learn (Karahan, 2007). Although there are considerable numbers of studies about the role of English in individuals' lives in different educational levels, there is little study which specifically investigates the views of students studying at vocational school. Thus, this study will explore and understand the views of ten students on the role of English in their lives. A qualitative method will be used in order to get detailed information just as Creswell (2012) describes that qualitative research provides deep insights into the central phenomenon that we need. In the light of this purpose, the following research question will be answered in the scope of this study.

\section{Research questions:}

1. What are the views of students on the role of English in their lives in terms of their professional and their social life?

\section{METHODOLOGY}

\section{Participants:}

The participants of this study were ten students who are studying at Tourism and Hotel Management Program and Accounting and Tax Applications program in a vocational school. These students have four hours English classes a week during four terms. They take English class as YOK course during first two terms and they take vocational English course in the third and the fourth terms. This study takes place in their third term at the vocational school. Furthermore, these students have been learning English since the primary school. The demographic information of the participants is illustrated in Table 1 below. 
Table 1

The demographic information of participants

\begin{tabular}{lll}
\hline $\begin{array}{l}\text { Participant } \\
\text { number }\end{array}$ & Gender & Program \\
\hline M1 & Male & Tourism and Hotel Management \\
M2 & Male & Tourism and Hotel Management \\
M3 & Male & Accounting and Tax Applications \\
M4 & Male & Accounting and Tax Applications \\
M5 & Male & Accounting and Tax Applications \\
F1 & Female & Tourism and Hotel Management \\
F2 & Female & Tourism and Hotel Management \\
F3 & Female & Tourism and Hotel Management \\
F4 & Female & Accounting and Tax Applications \\
F5 & Female & Accounting and Tax Applications \\
\hline
\end{tabular}

As the Table 1 describes above, there are three female and two male students from Tourism and Hotel Management program and three male and two female students from Accounting and Tax Applications participated in this study from three programs.

\section{Data Collection:}

The purpose of this study is to explore the views of student studying at vocational school on the role of English in their lives in terms of their professional and their social life in depth. For this reason, the central phenomenon of this study is the perceptions of Turkish vocational school students on the role of English in their lives. Regarding the purpose of the study and the central phenomenon of the study, qualitative research method is applied.

As a form of data collection semi-structured interview was applied in this study. Interview questions were prepared regarding students' future professional and their social life. The researcher discussed the interview questions with her colleague and made necessary changes. The interviews were carried out in Turkish, which is the interviewees' native language and they can express themselves in their native language more easily and comprehensively than English in which they are not proficient enough.

Before the interview researcher gave information about the study and its aim and asked the interviewee to sign the consent form. Then, interview started with the first interview question. Each interview lasted from 5 minutes to 8 minutes in the researcher's office. Each interview was audio-taped with the permission of the interviewee. The audio-taped interviews were transcribed for the data analysis.

\section{Data Analysis:}

The transcribed data was analyzed by the researcher regarding the steps of qualitative data analysis. First of all, researcher read the data many times. Then, she highlighted the repeated expressions and identified five codes as follows: positive attitudes, negative attitudes, profession, communication, entertainment. Finally, these five codes were reduced to 2 themes by grouping the similar codes in order to "form a major idea in the data"(Creswell, 2012:245). Consequently, the first theme was identified as "Perceptions of students towards learning English" and it consisted of two codes and they are: "positive attitudes and negative attitudes". The second theme was "reasons to learn English" and it included three codes which were "profession, communication, entertainment". All codes and themes were derived from the data by the researcher (See the Table 2 for the summary of coding process) 


\section{Table 2}

The Coding Process in the Study

\begin{tabular}{ll}
\hline Step & Process \\
\hline Step 1 & Read the whole transcribed data many times \\
Step 2 & Highlight the repeated expressions \\
Step 3 & Identify five codes \\
Step 4 & Group the similar codes \\
Step 5 & Reduce five codes to 2 themes \\
\hline
\end{tabular}

As it is showed above in the analysis of qualitative data thematic analysis was used for this study. Consequently, from codes to the themes were reached by the researcher. The codes were interrelated with their themes.

\section{RESULTS}

This study was carried out in order to understand vocational school students' views on the role of English in their lives in terms of their professional and their social life. The analysis of conducted interviews revealed two themes which are the perceptions of students towards learning English and their reasons to learn English.

The first theme of "perceptions of students towards learning English" consists of two codes which are stated as positive attitudes and negative attitudes. Furthermore, another theme of this study is students' reasons to learn English. This theme has also three codes listed as follows: profession, communication and entertainment (See Figure 1 below for the summary of themes and codes of this study).

\section{Figure 1}

Thematic Analysis of the Interviews: Themes and Codes with the Number of References

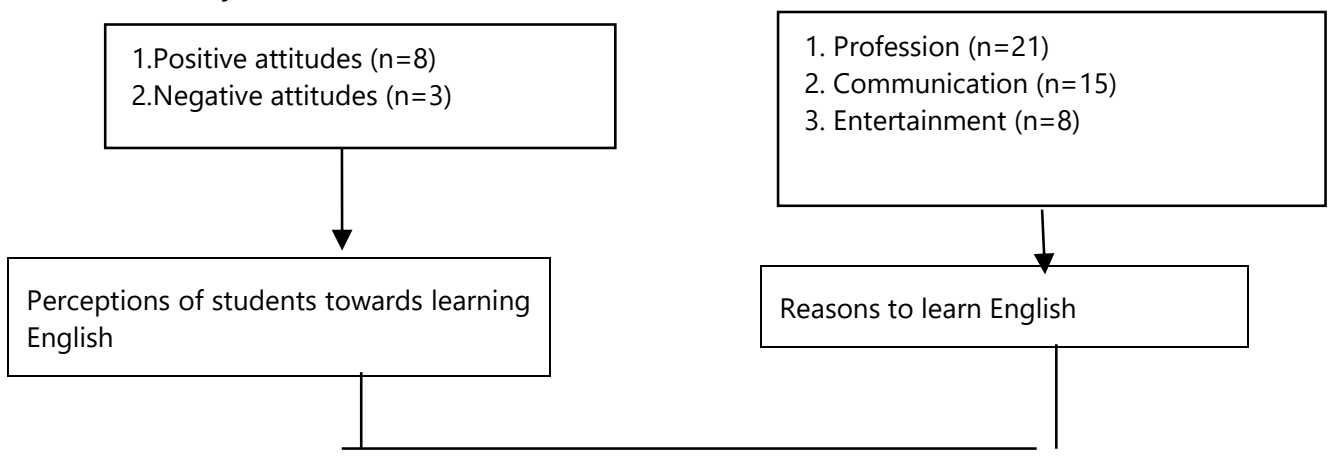

Perceptions of students towards learning English and

their reasons to learn English have an impact on

the views of students studying at vocational school on the role of English in their lives in terms of their professional and their social life

Based on the themes and codes, the results of current study will be presented in the following part and the results will be supported by the quotations of participants. 


\section{Perceptions of students towards learning English}

This theme "Perceptions of students towards learning English" includes two codes. One of them is students' positive attitudes and the other one is students' negative attitudes. Regarding the first code of positive attitudes of learners towards learning English it is revealed that 7 out of 10 students love, learning English and they believe that it is important and necessary for now and for their future profession. 2 students of 10 students state that they do not want to learn English since it is difficult for them. Finally, one of the studentshas both positive attitudes and negative attitudes towards learning English.

With the utterance of M1 positive attitudes can be exemplified. He states that "internet sayfalarında sürekli Ingilizce kelimeler olduğu için bana gerekli geliyor. Ailemde yabancı birileri olduğu için iletişim kolaylığı sağlıyor o yüzden önemli benim için" "It is necessary for me since there are always English words on the internet pages. It makes communication easy since there are foreign people in my family. Thus it is important for me). F3 also mentions about the importance of English for her life "Ben ileride yurtdışına gitmeyi düşünüyorum. Bu yüzden çok önemli benim için Ingilizce" (I am planning to go abroad for the future. Therefore, English is so important for me). Furthermore, F4 emphasizes the role of English in her life and notes that "Ingilizcenin hayatımdaki yeri büyük şu anki staj döneminden beri de Ingilizce'yi kullanıyorum" (The role of English is great in my life, I have been using English since the current period of my training). Finally, M4 stresses a different point for his learning with these words "Ingilizce hayatımda önemli uluslar arası bir dil olduğu için" (English is important in my life since it is an international language).

Another code which is related to students' negative attitudes towards learning English indicates that 2 students out of 10 students perceive English as unnecessary language for their life and difficult to learn. M5 talks about his negative attitudes towards learning English and he states that "ilkokuldan beri ingilizce öğreniyorum. Ingilizce çok gereksiz bir şey bence. Ben öyle görüyorum açıcası" (I have been learning English since primary school. I think English is such an unnecessary thing. Actually, I see it like that). Similarly, F5 states "Ben 4. Siniftan beri Ingilizce dersi görüyorum şu an üniversitedeyim ama hala hiçbir şey öğrenebildiğimi düşünmüyorum" (I have been taking English class since the fourth grades and now I am at university but I still don't think I could learn anything). She notes a reason for her failure "Öğrenim hayatının kötülüğünden ya da Ingilizce dersinin gereksizliğinden olabilir" (This might be because of bad education or unnecessariness of English lesson).

Furthermore, these two codes reveal that 1 out of 10 students has both positive attitudes and negative attitudes towards learning English and she cannot say with exact words "I love English or I hate English" Her feelings are complicated. Therefore, I haven't discussed it under a different theme. Instead, I will exemplify what she feels and thinks about learning English from her quotation. For example, F1 expresses her feelings "Ben Ingilizce ögrrenmeyi çok seviyorum ama bir türlü ögrenemiyorum" (I like learning English very much, but I cannot learn it somehow) and she provides the underlying reasons "Hocalardan kaynaklı olduğunu düşünüyorum çünkü şimdiye kadar kimse iyi öğretmiyor. Kursa bile gittim ben yine ögrenemedim diyebilirim" (I think that is because of teachers since nobody can teach well until now. I can say that I even attended course and I still could not learn it).

As a conclusion, all of the students in this study state that they have been learning English since they were fourth grades. Many of them believe that English as a global language is necessary and important for them and they love learning English while others don't like learning English and one student does not have exact positive or negative attitudes. Even these students who state that they don't like learning English give reasons to learn English. Therefore, the following theme was identified as "Reasons to learn English" and this will be discussed below. 


\section{Reasons to Learn English}

This category "Reasons to learn English" consists of three codes which are identified as follows: Profession, communication, entertainment. The first code profession as a working benefit of English is the main reason of students to learn English (21 references across 10 interviews). All the students believe that they will use English in their profession and English also will help them to build a successful career. Some of their utterances are listed below:

F1: "Bu bölümde çalışırsam büyük ihtimalle ingilizceyi kullanacağım seyahat acentasında ya da havalimaninda" (If I work in this profession, most probably I will use English at the travel agency or at the airport).

F2: "Personel olarak devam ettiğinde ilk istenen şey Ingilizce oluyor otelcilik mesleğinde" (When you work as a staff in a hotel, the first prerequisite is English).

M2: "Iş hayatında yükselmek için gerekli" (It is necessary to promote in professional life).

F4: "Müşterilerimiz yabancı olduğu için Türk misafirimiz yok Ingilizce'yi kullanmak zorunda hissediyorum" (Since our guests are foreign, we do not have any Turkish guests, I have to feel to use English).

M4: "Yabancı şirketlerde çalıştığım zaman ya da uluslararası bir şirkette ya da yurtdışına çıkma durumum olsa o zaman kullanacağımı düşünüyorum" (When I work in a foreign company or an international company or if I go abroad, I think I will use it then ).

As it is understood from the quotations, not only the students at Tourism and Hotel Management Program but also the students at Accounting and Tax Applications Program state that they will use English in their jobs. Even students (M5 and F5) who have negative attitudes toward English state that English will be necessary for their future profession. For example M5 utters "Meslek hayatımda kullanabilirim" (I can use English in my professional life).

After presenting the main reason (profession) which makes students learn English, the second reason of them is communication as a socio-cultural benefit of English (15 references across 10 interviews). F2 expresses her thought and feeling about communication "insanlarla iletişim önemli mesela karşınıza birisi geldiğinde ona cevap verememek insanı gerçekten kötü bir duruma düşürüyor"(Communication with people is important, for example, when there is someone opposite you, being unable to give an answer to him will make you be in a bad position). Moreover, M5 states that English is a need both for profession and communication and he utters that "iş hayatında yabancı insanlar karşıma çıkabilir ve insanlarla konuşma ihtiyacı duyduğum için Ingilizce gerekli" (I can meet foreign people in professional life and English is necessary since I need to talk to people). Finally, F4 puts emphasis on English for communication purposes and notes "Telefon görüşmelerimde ingilizce kullanıyorum çünkü yabancı misafirlerimiz var bizim" (I use English on phone calls since we have foreign guests).

The last code of this theme is entertainment as a socio-cultural benefit of English (8 references across 10 interviews). Students use English to watch movies, to sing songs, to play online games or to make jokes with their friends. Each of them will be supported with the quotation of students. M1 and M2 state that "Film izliyorum sürekli Ingilizce" (I always watch films in English) and "Haftada bir film Ingilizce film izliyorum" (I watch a film in English once a week), respectively. Moreover, F1 use English for songs and says "Ben kendi kendime şarkı söylüyorum Ingilizce" (I sing English songs myself). But male students use English to play online games and M3 states "Bazı oynadığım online oyunlar var onlarda Ingilizce kelime çok geçiyor" (There are some online games that I playand there are many English words in them). While making jokes, F4 uses English and she mentions "arkadaşlarımla şaka falan yaparken ingilizce konuşuyoruz" (While making jokes with my friends, we speak English).

Consequently, apart from $\mathrm{F} 5$ and M5, most of the students have positive attitudes towards learning English and during the interviews they state that they learn English and they believe that 
they will use it for profession and communication purposes. Furthermore, they also mention that they use English in their daily life while watching films or playing games.

\section{DISCUSSION AND CONCLUSION}

In the current study, the perceptions of students studying at vocational school about the role of English in their lives were explored in terms of their professional and their social life. First of all, the results of this study show that most of the students have positive attitudes towards learning English and they claim that learning English as a global language is important and necessary for their daily life and for their job, as well. According to Bani-Khalad (2014) and Karahan (2007), attitudes of students towards language learning would affect their language learning. Therefore, their positive attitudes affect their foreign language learning process positively since they will be more motivated to learn language and they have an active role in language learning. In the end this will bring success for them.

Next, as a result of education reform in 1997 which changed compulsory education from five to eight years and foreign language (English) starts to be taught in primary school (Sarıçoban, 2012), all the participants in this study started to learn English in the fourth grades. Some of the students believe that they could not learn anything though they like learning English at first. This finding suggests that it is the consequence of long process for language learning and it affects their feelings and thoughts adversely and students cannot feel successful during their language education. Students claim that the underlying reason is the lack of continuity in language education. As Erdel and Akalın (2015, p. 34) put forward, this problem could be eliminated by providing "continuity in language education between primary, secondary and tertiary levels".

Then, it was revealed that students learn English for three purposes as follows: profession, communication and entertainment. That is, they benefit from English economically and socioculturally. They believe that English will help them to have a well-paid job or to promote in their job. This conforms to the results of Genesee and Cloud, 1998; Jeffery, 2008; Singhal, 1997; Tomak, 2011) who state that students want to learn English since English is a must in order to get a good job. This result suggests that students learn English for working benefits. Therefore, these students will actively participate in language learning since they are studying at university and they are aware of the responsibilities for their future.

Another reason of students to learn English is for communication as a socio-cultural benefit and this result is found out by various studies, as well (Hann et al., 2014; Önder-Özdemir, 2014; Tomak, 2011). Students state that they need to communicate with people by means of English while they are working, having vacation or going abroad. Therefore, students' communicative competence besides linguistic competence should be improved and their communicative strategies should be developed in language teaching process, as well.

The last reason of students to learn English is entertainment as a socio-cultural benefit. Students need English while playing online games, watching films or making jokes with their friends. That is, while having fun, they need English.

Finally, based on the results of this study students studying at vocational school do not use English to read news or studies or to gather information related to their own programs. It could be concluded that their academic English is not good enough to follow the studies and news. They should be helped to improve their academic English to follow the changes and survive in them.

As a conclusion, students studying at vocational school have positive attitudes towards English and they know the importance of English in terms of their social and professional life in Turkey but two students (one female and one male) studying at Accounting and Tax Applications Program have negative attitudes. Even these students having negative attitudes towards English 
give reasons to learn English for their profession. Students studying at vocational school benefit from English in their professional and their social life. That is, they make use of working and sociocultural benefits of English rather than cognitive and educational benefits. As a future work a study in the same context may be conducted in order to investigate why students do not make use of cognitive and educational benefits of learning English. Furthermore, for further research findings should be supported by the quantitative data in order to make objective and reliable predictions through the opinions of a large number of participants.

\section{REFERENCES}

Bani-Khalad, T.A.A. (2014). The role of English as perceived by students of applied English at the university of Jordan. European Scientific Journal, 10 (5), 400-420.

Bialystok, E.,\& Hakuta, K. (1994). In other words: The science and psychology of second-language acquisition. New York: Basic Books.

British Council (2013). The English effect. Retrieved from https://www.britishcouncil. org/sites/default/ files/english-effect-report-v2.pdf.

Creswell, J.W. (2012). Educational research: Planning, conducting, and evaluating quantitative and qualitative research (4th edition). Boston: Pearson Education

Dogancay-Aktuna, S. (1998). The spread of English in urkey and its current sociolinguistic profile. Journal of Multilingual and Multicultural Development, 19(1), 24-31.

Doms, D. (2003). Roles and impact of English as a global language.MA TEFL/TESL(ODL). University of Birmingham, Birmingham.

Erdel, D.,\& Akalın,S. (2015). Evaluating English language course in a Turkish university. Journal of Educational and Instructional Studies in the World, 5(4), 26-35.

Eurumonitor International (2010). The benefits of the English language for individuals and societies: Quantitative indicators from Cameroon, Nigeria, Bangladesh and Pakistan. A custom report compiled by Euromonitor -International for the British Council.

Genesee, F.,\& Cloud, N. (1998). Multilingualism is basic. Educational Leadership, 55(6), 62-65.

Gömleksiz, M.N. (2010). An evaluation of students' attitudes toward English language learning in terms of several variables. Procedia-Social and Behavioral Sciences, 9, 913-918.

Hann, N., Timmis, I., Alkhaldi,A.A., Davies, B., Troncoso, C.R., \& Yi,Y. (2014). The impact of English on learners' wider lives. British Council. Retrieved from https://www.teachingenglish.org.uk/sites/teacheng/files/E085\%20Impact\%20of\%20English\%20o n\%20learners'_A4_web_FINAL.pdf.

Jeffery, L. (2008). Early language learning research. White Paper Report.

Johnson, K.(2013). An introduction to foreign language learning and teaching. New York: Routledge.

Karahan, F. (2007). Language attitudes of Turkish students towards the English language and its use in Turkish context. University of Çankaya Faculty of Science and Literature Journal of Arts and Sciences, 7, 73-87.

Oroujlou, N., \& Vahedi, M. (2011).Motivation, attitude, and language learning. Procedia-Social and Behavioral Sciences, 29, 994-1000.

Önder-Özdemir, N. (2014). The role of English as a lingua franca in academia: The case of Turkish postgraduate students in an Anglophone-centre context. Procedia-Social and Behavioral Sciences, 141, 74-78.

Özen, E.F., Alpaslan,I.B., Çağlı, A., Özdoğan,I., Sancak,M., Dizman,A.O., \& Sökmen, A. (2013). Turkey national needs assessment of state school English language teaching. Retrieved from http:// www.britishcouncil.org.tr/sites/default/files/turkey_national_needs_assessment_of_state_school_ english_language_teaching.pdf

Öztürk, Z. (2015). Opinions of university preparatory school students towards the effects of learning English on their career. Procedia-Social and Behavioral Sciences, 199, 785-792.

Sarıçoban, G. (2012). Foreign language education policies in Turkey. Procedia-Social and Behavioral Sciences, 46, 2643-2648.

Singhal, M. (1997). The internet and foreign language education: Benefits and challenges. The Internet TESL Journal, 3:6. Retrieved from http://iteslj.org/Articles/Singhal-Internet.html.

Stewart, J.H. (2005). Foreign language study in elementary schools: Benefits and implications for achievement in reading and math. Early Childhood Education Journal, 33(1), 11-16. 
Tardy, C. (2004). The role of English in scientific communication: lingua franca or Tyrannosaurus rex?. Journal of English for Academic Purposes, 3, 247-269.

Tomak, B. (2011). The perspectives of both Turkish students and Turkish teachers on English learning/teaching as an international language. $2^{\text {nd }}$ International Conference on ew Trends in Education and Their Implications, 277-285.

Uztosun, M.S. (2011). A qualitative study into English language teachers' and students' beliefs and practices in Turkey. The International Journal of Research in Teacher Education, 2(2), 16-34.

Weatherford, H.J. (1986). Personal benefits of foreign language study. ERIC Digest. U.S.: District of Columbia. Retrieved from http://www.ericdigests.org/pre-924/study.htm.

Zaim, C. (2011). Benefits of learning a foreign language. Retrieved from http://www.academia.edu/6580048/AFE_155_Benefits_of_Learning_a_Foreign_Language. 


\title{
Meslek Yüksekokulu'nda Okuyan Öğrencilerin İngilizce'nin Hayatlarındaki Rolü ile ilgili Görüşleri ve İngilizce Öğrenme Sebepleri
}

\author{
Semahat Aysu (Öğrt.Gör.) \\ Tekirdağ Namık Kemal Üniversitesi-Türkiye \\ saysu@nku.edu.tr
}

\begin{abstract}
Özet
Türkiye'de uzun yıllardır Ingilizce yabancı dil olarak öğrenilmekte ve öğretilmektedir. Ingilizce'nin öğrencilerin yaşamı üzerine rolü pek çok çalışmaya konu olmasına rağmen, şu ana kadar meslek yüksekokullarında okuyan ögrrencilerin görüşleri araştırılmamıştır. Bu yüzden bu çalışmanın amacı meslek yüksekokulunda okuyan öğrencilerin Ingilizce'nin mesleki ve sosyal yaşamlarını nasıl etkilediğine dair görüşlerini ortaya koymaktır. Çalışmanın amacı göz önünde bulundurularak nitel bir çalışma metodu uygulandı. Turizm ve Otel işletmeciliği ve Muhasebe ve Vergi Uygulamalarında okuyan 10 gönüllü öğrenci yarı yapılandırılmış görüşmeye katıldı. Görüşmelerden elde edilen veriler tematik analiz kullanılarak analiz edildi. Sonuçlar, öğrencilerin Ingilizce ögrenmeye karşı algıları ve Ingilizce ögrenme sebepleri olmak üzere iki tema ortaya çıkardı. ilk tema, olumlu ve olumsuz davranışlardan oluşmaktadır ve diğer temanın ise "meslek, iletişim ve eğlence" olmak üzere üç kodu vardır.
\end{abstract}

Keywords: Ingilizce öğretimi, Ingilizce öğrenme, Meslek Yüksekokulu, Yabancı dil

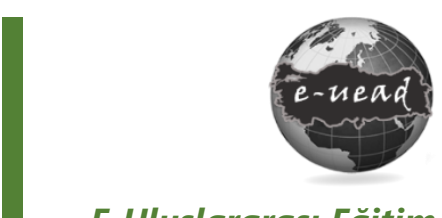

E-Uluslararası Eğitim Araştırmaları Dergisi, Cilt: 10, Sayt: 1, 2019, ss. 1-14

DOI: : 10.19160/ijer.392673

Gönderim : 09.03.2018

Revizyon 1(Varsa): 26.05.2018

Kabul : 25.01.2019

\section{Önerilen Atıf:}

Aysu, S. (2019). Meslek Yüksekokulu'nda Okuyan Öğrencilerin İngilizce'nin Hayatlarındaki Rolü Ille İlgili Görüşleri ve İngilizce Öğrenme Sebepleri, E-Uluslararası Eğitim Araştırmaları Dergisi, Cilt: 10, Sayı: 1, 2019, ss. 1-14,

DOI:10.19160/ijer.392673 


\section{GENIŞLETILMIŞ ÖZET}

Problem: Literatürde Ingilizce'nin insan hayatındaki rolünü içeren çalışmalar; Ingilizce öğrenmeye karşı öğrenci tutumlarının, Ingilizce öğrenmedeki başarı tahmincilerinden biri olduğunu (Gömleksiz, 2010) ve ögrencilerin negatif tutumlarının belirlenmesi öğretmenlere bu tutumları pozitife çevirmede bir fırsat sağlayacağını (Oroujlou and Vahedi, 2011) göstermiştir. Bunun yanısıra, ögrencilerin ingilizce ögrrenme sebeplerini bilmek ve bu doğrultuda öğrencileri motive etmek dil öğrenim ve ögrretim sürecininin etkinliğini arttıracaktır (Hann et al., 2014) e öğrenciler Ingilizce öğrenmek için derse aktif bir şekilde katılacalartır (Karahan, 2007). Ingilizce' nin bireyin hayatındaki rolü konusunda farklı eğitim seviyelerinde oldukça çok çalışma olmasına rağmen meslek yüksekokulu ögrrencilerinin görüş ve algılarını içeren çalışma yok denecek kadar azdır. Bu yüzden, bu çalışma ingilizce'nin meslek yüksekokulu öğrencilerinin hayatlarındaki yeri ve rolü konusunda görüş ve algılarını belirlemeyi amaçlamaktadır.

Yöntem: Bu çalışmanın amacı Türk meslek yüksekokulu öğrencilerinin Ingilizce'nin hayatlarındaki yeri ve rolü konusunda görüş ve algılarını belirlemektir. Bu amaç doğrultusunda, çalışmada nicel araştırma yöntemi kullanılmıştır. Veri toplama aracı olarak yarı yapılandırılmış görüşme soruları araştırmacı tarafından hazırlanmıştır. Görüşmeler, katılımcıların ana dili olan Türkçe dilinde yapılmıştır. Görüşme başlamadan, araştırmacı, katılımcılara çalışma ve amacı hakkında bilgi verip katılımcılardan görüşmeye katılım izin formunu imzalamalarını istemiştir. Sonrasında görüşme başlatılıp katılımcının izni doğrultusunda ses kaydı yapılmıştır. Son aşama olarak ses kayıtları, veri analizi için transkript yapılmıştır. 10 meslek yüksekokulu öğrencisi ile görüşme yapılmıştır. 3 bayan ögrrenci ve 2 erkek öğrenci Turizm ve Otel işletmeciliği programı ögrencisi ve 3 erkek ile 2 bayan ögrrenci Muhasebe ve Vergi Uygulamaları programı öğrencisidir. Görüşmelerden elde edilip transkript edilen veriler nitel araştırma yöntemi adımları kullanılarak analiz edilmiştir. Ilk olarak, veriler pek çok kez araştırmacı tarafından okunup, tekrar eden ifadeler belirlenmiştir. Bu doğrultuda kod ve temalar belirlenmiştir.

Sonuçlar ve Tartışma: Veri analizi sonucunda iki tema belirlenmiştir: "Öğrencilerin Ingilizce öğrenmeye karşı tutumları" ve "Ingilizce öğrenme sebepleri". Birinci tema, "öğrencilerin Ingilizce öğrenmeye karşı tutumları" iki koddan oluşmaktadır: "Pozitif tutumlar" ve "negative tutumlar". Ikinci tema ise "ingilizce öğrenme sebepleri" üç koddan oluşmaktadır: "Meslek", "iletişim" ve "Eğlence". ilk olarak, bu çalışmanın sonucunda katılımcıların çoğunun ingilizce öğrenmeye karşı olumlu tutumları olduğu saptanmıştır. Katılımcılar, Ingilizce'nin global bir dil olduğu için önemli olduğunu ve günlük ya da mesleki yaşamları için ingilizceye ihtiyaç duyduklarını iddia etmişlerdi. ikinci olarak, 1997 yılındaki eğitim reformu ile zorunlu eğitim beş yıldan sekiz yıla çıkmış ve yabacı dil (Ingilizce) öğretimi ilkokulda öğretilmeye başlamıştır (Sarıçoban, 2012). Bu yüzden bu çalışmadaki katılımcıların hepsi ilkokul dördüncü sınıfta Ingilizce öğrenmeye başlamışlardır. Katılımcıların bazıları, başlangıçta Ingilizce öğrenmeyi sevseler dahi hiçbir şey öğrenemediklerini belirtmişlerler. Bu sonucun altında yatan sebebi de katılımcılar dil eğitiminde devamlılığın olmaması olarak dile getirmişlerdir. Erdel and Akalın (2015) da belirttiği gibi bu sorun ancak ilkokul, ortaokul ve lisedeki dil eğitimde devamlılk ile ortadan kaldırılabilir. Sonrasında katılımcılar, ingilizce'yi öğrenme sebeplerinden biri olan mesleki hayatları için Ingilizce öğrenme isteklerini iyi maşlı bir iş̧e çalışmak ya da işlerinde kolayca terfi almak olarak açıklamışlardır. Bu sonuçlar literatürdeki diğer çalışmaların sonuçları ile de uyuşmaktadır (Genesee and Cloud, 1998; Jeffery, 2008; Singhal, 1997; Tomak, 2011). Başka bir sonuç ise katılımcılar Ingilizce' yi, bir işte çalışırken, tatile çıktıklarında ya da yurt dışına gittiklerinde iletişim kurmak için öğrenmek istiyorlar. Bu sonuç da literatürdeki diğer çalışma sonuçlarını desteklemektedir (Hann et al., 2014; Önder-Özdemir, 2014; Tomak, 2011). Son olarak, katılımcılar, Ingilizce' yi çevrimiçi oyun oynamak, film izlemek ya da arkadaşları ile şaka yapmak için yani eğlenme amacı ile öğrenmek istiyorlar. Bu çalışmadan ayrıca şu sonuç ortaya çıkartılabilir: Meslek yüksekokulu ögrrencilerinin akademik amaçlar için ingilizce öğrenmeyi istemiyor ya da planlamıyor. Diğer bir deyişle alanları ile ilgili haberleri ya da gelişmeleri takip etmek için Ingilizce öğrenmek istemiyor. 